7. Abrosimov VN. Odyshka [Shortness of breath]. Pul'monologija: Nacional'noe rukovodstvo [Pulmonology: National leadership]. M: GEOTAR Media. 2009; 154-164.

8. Bjalovskij JuJu. Psihologicheskie i social'nye faktory perenosimosti odyshki [Psychological and social factors portability breathlessness]. Odyshka i associirovannye sindromy: sbornik nauchnyh trudov [Shortness of breath and the associated syndromes: a collection of scientific papers]. Rjazan'. 2005; 34-44.

9. Dembo AG. Chto takoe odyshka? [What is shortness of breath?]. Sovetskaja medicina [Soviet medicine]. 1982; 6: 53-56.

10. Mukharlyamov NM. Khronicheskaya nedostatochnost' krovoobrashcheniya: rukovodstvo po kardiologii red Chazov El [Chronic heart failure: A Guide to Cardiology, ed El Chazov]. M: Meditsina [M: Medicine]. 1982; 3 (Bolezni serdtsa [Heart diseases]): 543-605.

11. Abrosimov VN. Vizual'nyj analog odyshki, vozmozhnosti prakticheskogo primenenija [Visual analogue of breathlessness, the possibility of practical application]. Terapevticheskij arhiv [Therapeutic archives]. 1989; 3 : 126-127.

12. Borg G. Psychophysical bases of perceived exertion. Med Sci sport exerc. 1982; 14: 436-447.

13. Nedoshivin $A O$ et al. Issledovanie kachestva zhizni i psihologicheskogo statusa bol'nyh s hronicheskoj serdechnoj nedostatochnost'ju [Quality of life and psychological status of patients with chronic heart failure].
Serdechnaja nedostatochnost' [Heart failure]. 2000; 1 (4): 34-37.

14. Gendlin GE et al. Metodiki issledovanija kachestva zhizni u bol'nyh hronicheskoj serdechnoj nedostatochnost'ju [Methods of study of quality of life in patients with chronic heart failure]. Serdechnaja nedostatochnost' [Heart failure]. 2000; 1 (2): 210-212.

15. Rector TS, Cohn JN. Assessment of Patient Outcome with the Minnesota Living with Heart failure Questionnaire: Reliability and validity during a randomized, double -blind, placebo -controlled trial of pimobendan. Am Heart J. 1992; 124: 1017-1025

16. Votchal BE, Magazanik NA. Sovremennye predstavlenija ob odyshke [Modern views on dyspnea]. Klinicheskaja medicina [Clinical medicine]. 1966; 3: 15-17.

17. Breslin $E$ et al. Perception of Fatique and quality of life in patients with COPD. Chest. 1998; 114: 958-964.

18. Chernogorov IA. Grudnaja zhaba [Angina pectoris]. M: Medgiz. 1954; $93 \mathrm{p}$.

19. 19. Banzett RB, Moosavi ShH. Dyspnea and Pain: Similarities and Contrasts Between Two Very Unpleasant Sensations. APS Bulletin. 2001; 11(2): 678-680.

20. 20. Frankshtejn SI. Dyhatel'nye refleksy i mehanizmy odyshki [Respiratory reflexes and mechanisms of dyspnea]. M: Medicine; $205 \mathrm{p}$.

21. 21. Rose GA, Blackburn H. Cardiovascular survey methods: monog ser WHO. Geneva: WHO. 1968; 56: 316-318.

\title{
ANALYSIS OF MEDICAL REPRESENTATIVES' ACTIVITIES DIRECTED TO PHYSICIANS IN EGYPT
}

\author{
BAHLOL MOHAMMED MOSTAFA HOSSNI ABDELAZIZ, graduate student of the Departament of management \\ and economics of pharmacy, medical faculty, Russian People's Friendship University, Russia, 117198, Moscow, \\ Mikluho-Maklaj str., 21, build. 1, e-mail:Ph_hossni@yahoo.com, citizenship: Egypt \\ LAGUTKINA TATIANA P., D. Pharm. Sci. professor of the Department of management and economics of pharmacy, \\ medical faculty, Russian People's Friendship University, Russia, 117513, Moscow, Leninski av., 135-1-591, \\ e-mail: Lagutkina.t@gmail.com, citizenship: Russia
}

\begin{abstract}
Aim. This paper aims to investigate medical representatives' (a form of personal selling) activities directed to physicians in Egyptian pharmaceutical market. Materials and methods. Surveying through simple random probability sampling is the approach appropriate for broad and representative overview of situation in research. Therefore, a survey of 1068 physicians was conducted through interviews and establishing structured data collection questionnaire. Results and discussion. This is the first empirical paper to investigate medical representatives' activities directed to physicians in Egyptian pharmaceutical market. These activities include identifying of medical representatives' activities through analysis of their visits, type of information introduced by medical representatives to physicians, using of free samples by medical representatives and compliance to ethical criteria, the required personal qualities and educational level of medical representatives as seen by physicians. These findings are useful for managers in pharmaceutical industry. They can be also useful in other industries such as medical equipment. Conclusion. Pharmaceutical companies are widely employing medical representatives, as the most effective and widely-applied technique in Egypt, but they don't sometimes comply to pharmaceutical promotion ethical criteria. Aligning marketing management vision with market real situation will lead to synergism effect in employing medical representatives.
\end{abstract}

Key words: medical representatives, physicians, pharmaceutical market, Egypt.

For reference: Bahlol MM, Lagutkina TP. Analysis of medical representatives' activities directed to physicians in egypt. The Bulletin of Contemporary Clinical Medicine. 2016; 9 (1): 17-23.

\section{АНАЛИЗ ДЕЯТЕЛЬНОСТИ МЕДИЦИНСКИХ ПРЕДСТАВИТЕЛЕЙ В ЕГИПТЕ}

БАХЛОЛ МОХАММЕД МОСТАФА ХОССНИ АБДЕЛАЗИЗ, аспиранТ кафедры Управления и экономики фармации, медицинский факультет, Российский университет дружбы народов, Россия, 117198, Москва, ул. Миклухо-Маклая, 21, корпус 1, e-mail: Ph_hossni@yahoo.com, гражданство: Египет

ЛАГУТКИНА ТАТЬЯНА ПЕТРОВНА, докт. фарм. наук, профессор кафедры управления и экономики фармации, медицинский факультет, Российский университет дружбы народов, Россия, 117513, Москва, Ленинский проспект, 135-1-591, e-mail: lagutkina.t@gmail.com, гражданство: Россия 
Реферат. Цель - изучение деятельности медицинских представителей (форма личной продажи), направленной на врачей на египетском фармацевтическом рынке. Материал и методы. Изучение с помощью случайного отбора вероятностей - простой подход, который подходит для обширного и репрезентативного анализа ситуаций в области научных исследований. Опрос 1068 врачей был проведен с помощью интервью и формирования структурированной анкеты для сбора данных. Результаты и их обсуждение. Это первое эмпирическое исследование для изучения деятельности медицинских представителей, направленное на врачей на египетском фармацевтическом рынке. Эти мероприятия включают в себя идентификацию мероприятий медицинских представителей путем анализа их визитов, типа информации, представленной врачам медицинскими представителями, которые используют бесплатные образцы медицинской продукции и соблюдают этические критерии, необходимые личные качества и образовательный уровень (с точки зрения врачей). Эти данные полезны для руководителей в фрармацевтической промышленности. Они могут быть также полезны в других отраслях промышленности, таких как медицинское оборудование. Заключение. Фармацевтические компании широко используют медицинских представителей эффективной и широко применяемой техники в Египте, но они иногда не соответствуют этическим критериям продвижения лекарственных препаратов. Рассмотрение направления управления маркетингом совместно с реальной ситуацией на рынке приведет к эффекту синергизма в использовании медицинских представителей.

Ключевые слова: медицинские представители, врачи, фармацевтический рынок, Египет.

Для ссылки: Бахлол, М.М. Анализ деятельности медицинских представителей в Египте / М.М. Бахлол, Т.П. Лагуткина // Вестник современной клинической медицины. — 2016. — Т. 9, вып.1. — С.17-23.

ntroduction. Marketing promotion (or marketing

communications) is generally divided into two groups: mass communications and personal communications.

1 - Mass Communications include public relations, advertising and sales promotions.

2 - Personal Communications have two forms, i.e., personal selling and direct marketing. Sale to customers depends actually not only on working hard, but also on working smart. It provides two-way interactions between company and customers. The main idea is not only how pharmaceutical company can reach customers, but also how it can enable its customers reach it and its products. As a result of communications tools technological development, people are moving from traditional media (e.g., newspapers and fax) to advanced media (e.g., the internet and mobile phones). By the time, pharmaceutical companies move to new advanced communications media, because of cost effectiveness and ability of more targeted communications. Personalizing communications enable identifying the right time for the right action with more impact on the targeted customer.

In our previous research, we evaluated different marketing promotional tools and found that personal selling (a medical representative) is the most applied marketing promotional tool in Egyptian pharmaceutical market [1]. According to these results, our research aims to studying personal selling as an important promotional tool in Egyptian pharmaceutical market.

We investigated applying personal selling (employing medical representatives) in pharmaceutical field with physicians in Egypt by pharmaceutical companies.

Literature Review. A medical representative should be an active order taker who has the principle of personal selling and should not be a passive order taker. The SPIN (situation-problem- implication-need payoff) method helps sales people to be an active order taker:

1 - Situation questions: They address exploring the buyer's present situation and pertinent facts, e.g., which medical regime is proffered by physician.
2 - Problem questions: They address problems, dissatisfactions and difficulties that face customers, e.g., asking by medical representatives about physician experience with certain pharmaceutical product.

3 - Implication questions: They address effects and consequences of problems, dissatisfactions and difficulties that face customers, e.g., investigating and advising about managing certain drug adverse effects and pharmaceutical product interactions observed by physician.

4 - Need-payoff questions: They address proposed solutions; their usefulness and value, e.g., proposing company's pharmaceutical product and its effect on problem solving [2].

A medical representative should be effective in selling tasks with customers. His tasks should be professionally managed. To be effective and achieve sales target, he should perform as follows:

1 - Prospecting and Qualifying: pharmaceutical company and salesperson should identify and qualify prospects. The company recognizes targeted customers and categorizes them according to importance. These actions will help salesperson to efficiently use his time.

2 - Pre-approaching: a medical representative should gather effective information about customer organization, i.e., the hospital and the customer himself (the physician). Such information will help medical representatives to know how and who makes purchasing decision.

3 - Approaching: a salesperson should apply an appropriate technique to build a relationship with customer.

4 - Presentation and Demonstration: a medical representative demonstrates pharmaceutical product to customer through applying AIDA «i.e., Attention, Interest, Desire, Action» formula to communicate with the customer. In demonstrating pharmaceutical product, a medical representative should mention its FABV, i.e., features of physical character; advantages to customer; benefits of buying; and value.

5-Overcoming Objections: physician objections are divided to two types: firstly, psychological resistance, i.e., 
other brand loyalty, predetermined idea and unpleasant communication created by a medical representative; and secondly, logical resistance, i.e., pharmaceutical product features or price. A medical representative should ask the customer to clarify his objections, and apply his negations skills to solve them.

6 - Closing: there are closing signs from a customer that he is convinced and satisfied, e.g., commitment, comments or physical actions. A salesperson should know these signs and apply a closing technique, e.g., ask for the order of pharmaceutical product or help the secretary to write it.

7 - Follow-up and Maintenance: after making the order, a medical representative should ensure that his customer is repeatedly satisfied. He should keep in contact with customer and develop growth plan for the account $[3,4]$.

A medical representative has definite objectives, tasks and responsibilities. Objectives and strategy of medical representatives are to define and solve customer's problems and propose solutions thereof. A medical representative has one or more of the following objectives: Prospecting-finding prospect, targeting-allocating time among prospects and customers, communicating-presenting information about product or service, selling-solving problems and closing sales, servicing supporting customer with various services, e.g., counseling, Information gathering-Collecting information about market in research activities and Allocating-deciding customer's priority given to scare products in case of shortages.

Sales force compensation is an important issue. A pharmaceutical company should not only establish an attractive salary, but also design it carefully. It should take in its consideration four components of medical sales force compensation, i.e., a fixed salary, a variable amount, expense allowances and benefits. Firstly, a fixed salary supports income stability and secures income satisfaction. It will lead to decreasing turnover in the company, reducing customers overstock and medical representatives will be enhanced through conducting non selling activities of relationship building. Secondly, a variable amount has a lot of forms, e.g., bonus, commissions and profit sharing. It will lead to stimulation, motivation, focusing more on selling activities than relationship building, higher medical representatives performance, rewarding his effort with lower need to higher supervision and controlling selling cost. The company may connect variable salary with its strategic goals, e.g., customer satisfaction, geographical expansion and gross profit. Thirdly, expense allowances are expenses of subsistence and travel. Fourthly, benefits are supports of salesperson with job satisfaction and security, e.g., life insurance, accident benefits, paid vacation and pensions. A salesperson salary should be a combination of these components so as to increase their advantages and decrease their disadvantages [5].

Medical representatives usually become unmotivated, because of working alone away from home for a long time, experiencing different culture and philosophies, high competition, inferior status rela- tive to buyer and low authority in their sales area. Consequently, a medical representative has because of his job nature a continuous need to motivation. A pharmaceutical company should keep and increase motivation of its sales force by enhancing work environment, convincing salesperson that he can work harder or smarter by training him elegant methods. Managers should insist that rewards and commissions are worth in return for extra performance. A pharmaceutical marketer should enhance intrinsic and extrinsic rewards. A study revealed that rewards types have different importance degrees. Accordingly, the lowest values were related to liking, respect, security and recognition, whereas the highest values were related to pay, promotion, personal growth and accomplishment sense. These values will keep and enhance salesperson motivation [6-10].

In foreign pharmaceutical companies, their headquarter office usually organizes marketing activities and sends its decisions to marketing department in a definite country. This marketing department usually has minor roles in decision making and its main rule is related to implementing decisions taken by the company headquarter office. In a definite country, medical representatives have direct contacts with customers and know their needs. This situation leads to conflicts between marketing departments and sales force department. Enhancing coordination and collaboration between marketing department and sales force department and decreasing internal conflicts between them will lead to increasing sales, revenue and profits [11, 12].

To keep focusing on marketing management orientation, a medical representative should learn sales data analyzing, marketing strategies developing, marketing skills improving and marketing intelligence gathering. Medical sales force structure and strategy are correlated. A company should design a territorial structure in case of promoting a pharmaceutical product line to customers of the same specialty in many locations, but it should design a product or market structure in case of promoting many pharmaceutical products line to many types of customers.

Research Methods. This research aims to studying medical representatives' activities with physicians in Egypt. When we need a broad and representative overview of situation in research, survey is the appropriate approach [13]. Accordingly, for data gathering in this research we used the survey, where we resorted to personal interviews.

Sampling. In our research, we used simple random probability sampling, where physicians in Egypt were asked to answer questionnaires. In this study, we collected 1068 questioners from physicians at hospitals and clinics who answered questionnaires.

Data collection. In this research, we focused on medical representatives' activities with physicians in Egypt. Secondary and primary data were our information sources. Firstly, we started literature review of personal sales and promotion in pharmaceutical field. The next step was represented in establishing 
structured questionnaire for data collection from physicians.

For information collection, we used questioners and interviews with physicians. We applied the Statistical Package for Social Sciences (SPSS) software to develop valuable information from collected the questionnaires. Answering open-end questions was valuable as a source of qualitative information. We collected questionnaires over nine months (from Julay 2014 to May 2015).

Findings and Discussion. This research aims to studying application of personal selling with physicians. We had to solve the following issues:

1. Study of intermediate drugs customers (the physicians).

2. Characteristics of provided information.

3. Using of medical free samples.

4. Physicians requirements imposed to medical representatives.

5. Developing recommendations on applying personal selling with physicians in Egypt.

Study of Intermediate Drugs Customers (the Physicians). In this research, we collected questioners from 1068 physicians who have 18 specialties (see table 1).

Ta ble 1

Composition of Physicians (Respondent) by Specialty

\begin{tabular}{|l|c|c|}
\hline \multirow{2}{*}{ Specialty } & \multicolumn{2}{|c|}{ Number of Respondents } \\
\cline { 2 - 3 } & $\begin{array}{c}\text { Absolute } \\
\text { value }\end{array}$ & $\begin{array}{c}\text { Relative } \\
\text { Indicator, \% }\end{array}$ \\
\hline Gastroenterology & 258 & 24,2 \\
Pediatrics & 163 & 15,3 \\
Obstetrics and gynecology & 134 & 12,5 \\
General Medicine & 112 & 10,5 \\
Surgery & 85 & 8,0 \\
Dentistry & 77 & 7,2 \\
Dermatology & 53 & 5,0 \\
Orthopedics & 45 & 4,2 \\
Urology & 38 & 3,6 \\
Otolaryngology & 38 & 3,6 \\
Pulmonology & 28 & 2,6 \\
Cardiology & 17 & 1,6 \\
Ophthalmology & 9 & 0,8 \\
Physical Therapy & 5 & 0,5 \\
Psychiatry & 2 & 0,2 \\
Oncology & 2 & 0,2 \\
ICU & 1 & 0,1 \\
Neurology & 1 & 0,1 \\
\hline Total & 1068 & 100 \\
\hline
\end{tabular}

We found that physicians are divided into three groups according to educational level (see table 2): general practitioners, i.e., physicians with bachelor degree of medicine; specialists, i.e., physicians with master degree of medicine; and consultants, i.e., physicians with doctorate degree of medicine. Specialists represent half approximately of respondents.

Characteristics of Provided Information. An important point in medical representatives' activity is the information they provided and degree of trust with physicians. For studying physicians opinion on information provided by medical representatives for
Table 2

Grouping of Physicians (Respondents) by Socio-demographics

\begin{tabular}{|l|c|c|}
\hline \multirow{2}{*}{ Degree of Specialty } & \multicolumn{2}{|c|}{ Number of Respondents } \\
\cline { 2 - 3 } & $\begin{array}{c}\text { Absolute } \\
\text { value }\end{array}$ & $\begin{array}{c}\text { Relative } \\
\text { Indicator, \% }\end{array}$ \\
\hline General Practitioner & 157 & 14,6 \\
Specialist & 504 & 46,7 \\
Consultant & 418 & 38,7 \\
\hline Total & 1116 & 100 \\
\hline
\end{tabular}

drugs promotion, questions from the standard form of report according to which the independent French pharmaceutical bulletin "La Revue Prescrire» since 1991 that carries out monitoring pharmaceutical representatives behavior were brought in the questionnaire and provided estimates for information accuracy [14]. Therefore, we asked physicians about the most remembered visit of pharmaceutical companies' medical representatives to estimate contents of oral information provided by medical representatives who promote drugs (see table 3).

Table 3

Analysis of the Most Remembered Visit

by Medical Representatives of Pharmaceutical Companies

\begin{tabular}{|l|c|}
\hline \multicolumn{1}{|c|}{ Q14] } & $\begin{array}{c}\text { Percentage } \\
\text { of Physi- } \\
\text { Pharmaceutical Bulletin «La Revue Prescrire») } \\
\text { cians who } \\
\text { Answered } \\
\text { positively, } \\
\%\end{array}$ \\
\hline $\begin{array}{l}\text { Whether the mentioned indications coincide with } \\
\text { scientific medico-biological data? }\end{array}$ & 95,0 \\
\hline $\begin{array}{l}\text { Whether the regimen coincides with that } \\
\text { mentioned in scientific medico-biological data? }\end{array}$ & 92,3 \\
\hline $\begin{array}{l}\text { Whether medical representative mentioned } \\
\text { initiatively its side effects? }\end{array}$ & 26,2 \\
\hline $\begin{array}{l}\text { Whether medical representative initiatively } \\
\text { mentioned contraindications? }\end{array}$ & 37,5 \\
\hline $\begin{array}{l}\text { Whether medical representative initiatively } \\
\text { mentioned interactions with drugs? }\end{array}$ & 38,4 \\
\hline $\begin{array}{l}\text { Considering medicine type, do you think that } \\
\text { the medical representative should mention the } \\
\text { above-named information (see questions 3,4 } \\
\text { and 5)? }\end{array}$ & 86,5 \\
\hline $\begin{array}{l}\text { Whether the medical representative willingly } \\
\text { answered your questions concerning side } \\
\text { effects, contraindications and interactions with } \\
\text { drugs? }\end{array}$ & 87,8 \\
\hline $\begin{array}{l}\text { Whether you found information of medical } \\
\text { representative convincing? }\end{array}$ & \\
\hline $\begin{array}{l}\text { Did you provide any arguments for purpose of } \\
\text { this medicine before using it (for example, hints if } \\
\text { refusal will increase patients suffering or reduce } \\
\text { their chances of survival)? }\end{array}$ & \\
\hline
\end{tabular}

By examination of physicians - half approximately of information on drugs was incomplete $-87 \%$ of them found that the information provided by medical representatives (by physicians request, not by medical representatives initiative) was convincing. A little number of pharmaceutical companies' 
medical representatives gave complete information about promoted drugs by their initiative without physicians' pressure. Only $1.8 \%$ of physicians need information regarding pricing and $7 \%$ of them need information regarding pharmacological effect of comparable products (comparison of drugs with similar effects). This lead us to the question of information provided by medical representatives incompleteness and therefore lack of awareness to physicians with respect to both new and long-established drugs.

Using of medical free samples. The most common promotion technique applied by pharmaceutical companies in relation to physicians is represented in providing free sample drugs (which are not a batch of medicinal preparations). According to ethical criteria stated in directives of World Health Organization (WHO), European Economic Community (EEC) and the Marketing code of Mission pour la Facilitation d'Accès à la Fonction Publique (MFAFP); free samples of pharmaceutical drugs have to be provided by a label stating that they are complimentary. Each sample should be labeled as «not intended for sale» (or a similar label thereto) and supported by short description of product characteristics [15-19].

According to our research result, $88,7 \%$ of physicians mentioned that they received free medicines samples from medical representatives; $11,8 \%$ mentioned that they received them $1-3$ times per year; $10,9 \%$ mentioned that they received them 4-6 times per year; $27,8 \%$ mentioned that they received them $7-12$ times per year and about half of physicians, i.e., $49,5 \%$ mentioned that they received them more than 12 times per year (see figure 1). According to our research result, $85,8 \%$ of medical free samples were given by medical representatives' initiative and only $14,2 \%$ by physicians' request. In addition, $95,3 \%$ of physicians mentioned that free samples are labeled as (complimentary medical sample not for sale) and $91,7 \%$ mentioned that the free samples were supported by a short description of medicine characteristics. In conclusion, we can state that providing free medicines samples is a widelyapplied activity, however, providing such samples in practical real life does not follow ethical and legal requirements in all cases.

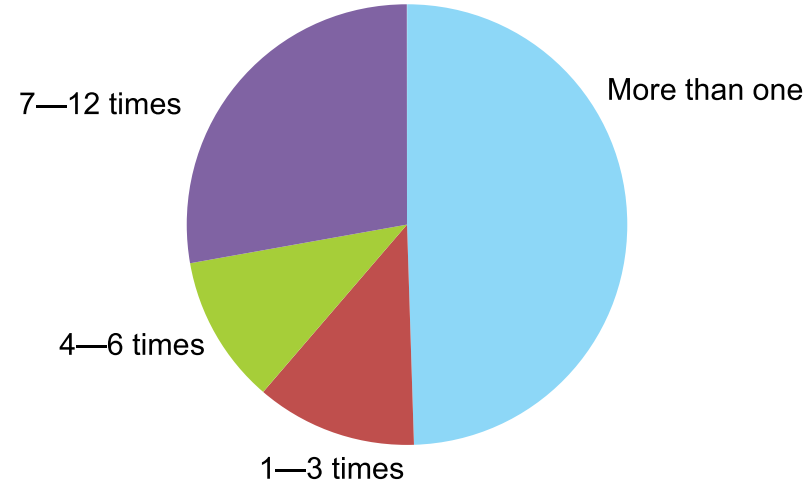

Figure 1. Number of Free Samples Given to a Physician per Year by Medical Representatives
Accordingly, a medical representative is a common means of pharmaceutical promotion applied with physicians by pharmaceutical companies in Egypt. The practice of employing a medical representative is a form of personal sales that is not always complying to pharmaceutical promotion ethical criteria. We should simultaneously mention that such type of drug promotion is the most effective and widely-applied technique by pharmaceutical companies in Egypt.

Physicians Requirements Imposed to Medical Representatives. There is a focus on requirements by physicians for medical representatives, because of their importance in putting marketing management vision in alignment with market real situation in order to achieve synergism effect in medical representatives hiring and employing.

With regard to medical representatives required education, $97,3 \%$ of physicians believe in the need for high specialized education and $2,7 \%$ believe in adequacy of medium specialized education for this job (see figure 2). Physicians who chose high specialized education mentioned the requirement of the following specialties: $9,6 \%$ of them insisted on the need for medical education, $19 \%$ insisted on the need for pharmaceutical education, $53,4 \%$ insisted on the need for medical or pharmaceutical education and $18 \%$ insisted on the need for any high specialized education (see figure 3).

With regard to the personal qualities required for a medical representative, $41,4 \%$ of physicians mentioned sociability, $25,4 \%$ mentioned sincerity, $23,6 \%$ mentioned convincablity, 6,6\% mentioned friendliness and $2,1 \%$ mentioned attentiveness. Therefore, $86,9 \%$ of physicians mentioned that medical representatives tried to build friendship (It is common in other countries).

Conclusion. According to educational level, physicians are classified into three groups: general practitioners, i.e., physicians with bachelor degree of medicine; specialists, i.e., physicians with master degree of medicine; and consultants, i.e., physicians with doctorate degree of medicine.

Medium special education

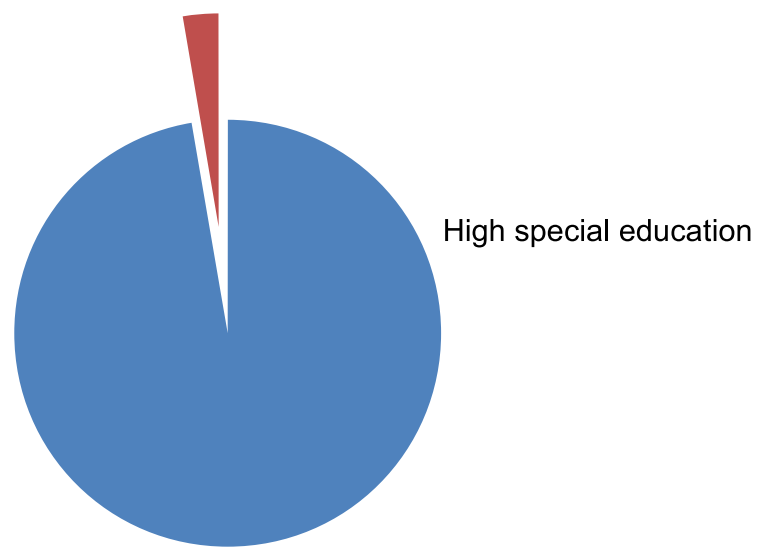

Figure 2. Educational Level of Medical Representatives as Required by Physicians 


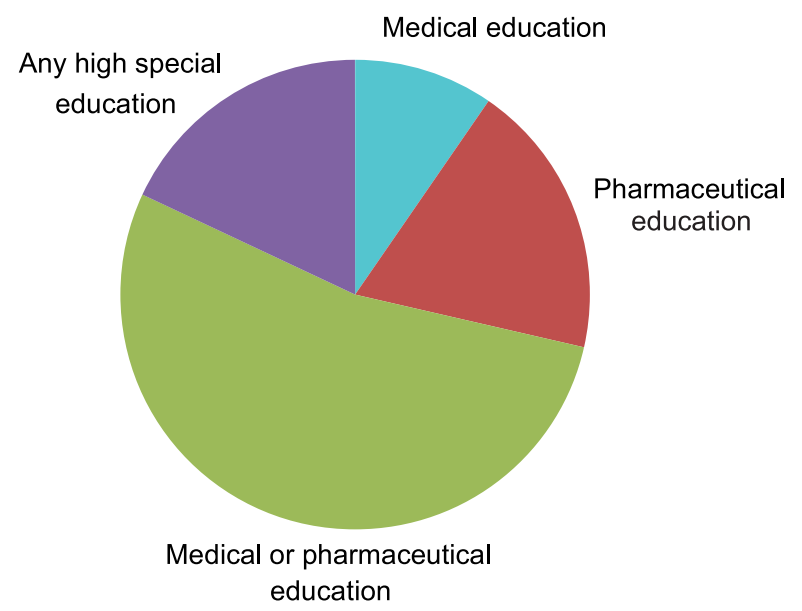

Figure 3. Specialty of Medical Representatives as Required by Physicians

By studying medical representives' activities directed to physicians, we applied the standard form of reporting of French pharmaceutical bulletin «La Revue Prescrire» to analyize the most remembered visit by pharmaceutical companies' medical representatives. We found that medical representatives mentioned indications of drug with regard to scientific medicobiological data in $95 \%$ of cases and the regimen coincides with what is mentioned in scientific medico-biological data in $92,3 \%$ of cases. Medical representatives initially mentioned side effects in $26,2 \%$ of cases, contraindications in $37,5 \%$ of cases and interactions with other drugs in $38,4 \%$ of cases. They willingly answered physicians' question concerning side effects, contraindications and drug interactions in $90,5 \%$ of cases. Physicians found medical representatives information as convincing in $87,8 \%$ of cases. Half of physicians mentioned that medical representatives provided incomplete information. This indicates information incompleteness and lack of physicians' awareness with respect to drugs. Thus, $1,8 \%$ of physicians were interested in information about pricing and $7 \%$ were interested in information about comparable products' pharmacological effect (comparison of drugs with similar effects).

Providing free sample drugs is the most common promotion technique applied with physicians. Providing free sample drugs by pharmaceutical companies' medical representatives does not always comply to ethical requirements. Both educational level and personal qualities of medical representivies are important as seen by physicians. There are certain educational requirements for medical representatives. All physicians approximately mentioned requirement of high specialized education and half approximately of them insisted on medical education requirement to be a medical representative. The most required personal quality of medical representatives as mentioned by physicians is sociability according to $41,4 \%$, followed by sincerity, convincability, friendliness and attentiveness. Most medical representatives tried to build friendship with physicians.
Finally, we can say that a medical representative (a form of personal sales) is widely employed by pharmaceutical companies in Egypt. Aligning marketing management vision with market real situation will lead to synergism effect in employing medical representatives. Medical representatives practice does not sometimes comply to pharmaceutical promotion ethical criteria. It is simultaneously the most effective and widely-applied technique by pharmaceutical companies in Egypt.

The transparency of study. The study did not have sponsorship. Authors are fully responsible for the provision of the final version of the manuscript for publication.

\section{ЛИТЕРАТУРА}

1. Лагуткина, Т. Изучение организационных аспектов продвижения на фрармацевтическом рынке Египта / Т. Лагуткина, М. Бахлол // Международный научноисследовательский журнал. - 2015. - Т. 4/3, вып. 35. - C.48-52.

2. Dixon, A.L. Successful and unsuccessful sales calls: Measuring salesperson attributions and behavioral intentions / A.L. Dixon, R.L. Spiro, M. Jamil // Journal of Marketing. — 2001. — № 65(3). - P.6478.

3. Kotler, P. Marketing management: A south Asian perspective / P. Kotler // Pearson Education India. — 2009. _ URL: http://www.abebooks.com/servlet/BookDetailsPL?bi=13 954160626\&searchurl=isbn\%3D9788131716830 (дата обращения: 26.01.2016).

4. Jackson, D.W. Selling: The personal force in marketing / D.W. Jackson, W.H. Cunningham, I.C. Cunningham // John Wiley \& Sons. - 1988. —URL: http://www.amazon. com/Selling-Marketing-William-J-E-Crissy/dp/0471637661 (дата обращения: 26.01.2016).

5. Gomez-Mejia, L.R. Managing human resources/ L.R. Gomez-Mejia, D.B. Balkin, R.L. Cardy // Prentice Hall Upper Saddle River. - 2004. — URL: https://www. google.com.eg/url?sa=t\&rct=j\&q=\&esrc=s\&source=we $\mathrm{b} \& \mathrm{~cd}=4 \& \mathrm{cad}=\mathrm{rja} \& u a c t=8 \& v e d=0$ ahUKEwjdwpK_qsfKA hXD83IKHaFbAuQQFggmMAM\&url=http $\% 3 \mathrm{~A} \% 2 \mathrm{~F} \% 2 \mathrm{~F}$ www.tuyiau.ac.ir\%2Ffa\%2Fcomponent $\% 2$ Fattachment s\%2Fdownload\%2F115\&usg=AFQjCNGmvUnjxfi-OTd KmVzRGqD4H4VooA\&bvm=bv.112766941,d.bGQ (дата обращения: 26.01.2016).

6. Krafft, M. An empirical investigation of the antecedents of sales force control systems / M. Krafft // The Journal of Marketing. - 1999. — № 1. - P.120-134.

7. Chu, W. Costs and benefits of hard-sell / W. Chu, E. Gerstner, J.D. Hess // Journal of Marketing Research. 1995. — № 1. - P.97-102.

8. Mantrala, M.K. Structuring a multiproduct sales quotabonus plan for a heterogeneous sales force: A practical model-based approach / M.K. Mantrala, P. Sinha, A.A. Zoltners // Marketing Science. — 1994. — № 13(2). P.121-144.

9. Chowdhury, J. The motivational impact of sales quotas on effort / J. Chowdhury // Journal of Marketing Research. 1993. — URL: http://search.proquest.com/openview/af11 6092ada9c9c81f717f9fa34f1d09/1?pq-origsite=gscholar (дата обращения: 26.01.2016).

10. Sales force management / G.A.Churchill [et al.] // Irwin: McGraw-Hill Boston, MA. - 2005. - URL: http://www. amazon.com/Churchill-Walkers-Management-Mcgraw- 
Hill-Marketing/dp/007296183X (дата обращения: 26.01.2016)

11. Kotler, $P$. Ending the war between sales and marketing / P. Kotler, N. Rackham, S. Krishnaswamy // Harvard Business Review. — 2006. — № 84 (7/8). P.68.

12. Smith, T.M. A three-stage model of integrated marketing communications at the marketing-sales interface / T.M. Smith, S. Gopalakrishna, R. Chatterjee // Journal of Marketing Research. — 2006. — № 43(4). — P.564579.

13. Fisher, $C$. Researching and writing a dissertation: a guidebook for business students / C. Fisher // Pearson Education. - 2007. — URL: http://www.amazon.co.uk/ Researching-Writing-Dissertation-Guidebook-Business/ dp/0273710079 (дата обращения: 26.01.2016).

14. Bardelay, $D$. Visits from medical representatives: Fine principles, poor practice / D. Bardelay, D. Bécel // Prescrire International. — 1995. — № 4(18). - P.120-122.

15. Code of Marketing Practices of the Association of International Pharmaceutical Manufacturers. - URL: http://www. ifpma.org/fileadmin/content/About\%20us/2\%20Members/ Associations/Code-Russia/1_RUS-EN-Code-2009[1].pdf (дата обращения: 26.01.2016).

16. Code of the International Federation of Pharmaceutical Manufacturers Associations. - URL: http://www.ifpma. org/fileadmin/content/Publication/2012/IFPMA_Code_ of_Practice_2012_new_logo.pdf (дата обращения: 26.01.2016).

17. Усенко, В. Лицензирование в Европейском союзе: фармацевтический сектор / В. Усенко, А. Спасокукоцкий. - Киев: Морион, 1998. - С.61-66.

18. Ethical WHO (21 Assembly of WHO, 1968, Resolution 21/41; 39 Assambel of WHO, 1986, Resolution 39/27; 47 Assembly of WHO, 1994, Report of the CEO of A47/7) URL: http://apps.who.int/iris/bitstream/10665/177057/1/ WHA47_A-Conf.Paper-2_eng.pdf (дата обращения: 26.01.2016).

19. Egyptian law of practicing pharmacy profession No 127/1955. — URL: http://pcm.me/ph-practice-law-in-egypt (дата обращения: 26.01.2016).

\section{REFERENCES}

1. Lagutkina T, Bahlol M. Izuchenie organizacionnyh aspektov prodvizhenija na farmacevticheskom rynke egipta [Survey on using marketing promotion by pharmaceutical producers in Egypt]. Mezhdunarodnyj nauchno-issledovatel'skij zhurnal [International research journal], 2015; 4-3 (35): 48-52.

2. Dixon AL, Spiro RL, Jamil M. Successful and unsuccessful sales calls: Measuring salesperson attributions and behavioral intentions. Journal of Marketing. 2001; 65 (3): 64-78.

3. Kotler P. Marketing management: A south Asian perspective: Pearson Education India; 2009 [cited 26 Jan 2016]. Available from: http://www.abebooks.com/servlet/ BookDetailsPL?bi=13954160626\&searchurl=isbn\%3D9 788131716830.

4. Jackson DW, Cunningham WH, Cunningham IC. Selling: The personal force in marketing: John Wiley \& Sons; 1988 [cited 26 Jan 2016]. Available from: http://www. amazon.com/Selling-Marketing-William-J-E-Crissy/ dp/0471637661.

5. Gomez-Mejia LR, Balkin DB, Cardy RL. Managing human resources: Prentice Hall Upper Saddle River; 2004 [cited
26 Jan 2016]. Available from: https://www.google.com.eg/ url?sa $=$ t\&rct=j\&q=\&esrc=s\&source $=$ web\&cd $=4 \& c a d=r j a \&$ uact $=8 \&$ ved $=0$ ahUKEwjdwpK_qsfKAhXD83IKHaFbAuQQ

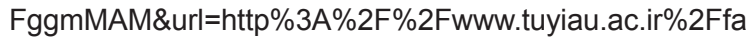
\%2Fcomponent\%2Fattachments\%2Fdownload\%2F115\& usg=AFQjCNGmvUnjxfi-OTdKmVzRGqD4H4VooA\&bvm $=$ bv. $112766941, \mathrm{~d} . \mathrm{bGQ}$.

6. Krafft M. An empirical investigation of the antecedents of sales force control systems. The Journal of Marketing. 1999; 1: 120-134.

7. Chu W, Gerstner E, Hess JD. Costs and benefits of hard-sell. Journal of Marketing Research. 1995; 1: $97-$ 102.

8. Mantrala MK, Sinha P, Zoltners AA. Structuring a multiproduct sales quota-bonus plan for a heterogeneous sales force: A practical model-based approach. Marketing Science. 1994; 13 (2): 121-144.

9. Chowdhury J. The motivational impact of sales quotas on effort. Journal of Marketing Research. 1993 [cited 26 Jan 2016]. Available from: http://search.proquest. com/openview/af116092ada9c9c81f717f9fa34f1d09/1 ?pq-origsite $=$ gscholar.

10. Churchill GA, Ford NM, Walker OC, Johnston MW, Tanner JF. Sales force management: Irwin/McGraw-Hill Boston, MA; 2005[cited 26 Jan 2016]. Available from: http://www. amazon.com/Churchill-Walkers-Management-McgrawHill-Marketing/dp/007296183X.

11. Kotler P, Rackham N, Krishnaswamy S. Ending the war between sales and marketing. Harvard Business Review. 2006; 84 (7/8): 68.

12. Smith TM, Gopalakrishna S, Chatterjee R. A three-stage model of integrated marketing communications at the marketing-sales interface. Journal of Marketing Research. 2006; 43 (4): 564-579.

13. Fisher $C$. Researching and writing a dissertation: a guidebook for business students: Pearson Education; 2007[cited 26 Jan 2016]. Available from: http://www.amazon.co.uk/ Researching-Writing-Dissertation-Guidebook-Business/ dp/0273710079.

14. Bardelay D, Bécel D. Visits from medical representatives: Fine principles, poor practice. Prescrire International. 1995; 4 (18): 120-122.

15. Code of Marketing Practices of the Association of International Pharmaceutical Manufacturers [cited 26 Jan 2016]. Available from: http://www.ifpma.org/fileadmin/ content/About\%20us/2\%20Members/Associations/CodeRussia/1_RUS-EN-Code-2009[1].pdf.

16. Code of the International Federation of Pharmaceutical Manufacturers Associations [cited 26 Jan 2016]. Available from: http://www.ifpma.org/fileadmin/content/ Publication/2012/IFPMA_Code_of_Practice_2012_new logo.pdf.

17. Usenko V, SpasokukockijA. Licenzirovanie v Evropejskom sojuze: farmacevticheskij sektor [Licensing in the European Union: the pharmaceutical sector]. K: Morion [K: Morion]. 1998; 61-66 p.

18. Ethical WHO (21 Assembly of WHO, 1968, Resolution 21/41; 39 Assambel of WHO, 1986, Resolution 39/27; 47 Assembly of WHO, 1994, Report of the CEO of A47/7) [cited 26 Jan 2016]. Available from:http://apps.who.int/iris/ bitstream/10665/177057/1/WHA47_A-Conf.Paper-2_eng. pdf.

19. Egyptian law of practicing pharmacy profession No 127/1955 [cited 26 Jan 2016]. Available from: http://pcm. me/ph-practice-law-in-egypt. 